\title{
Thermal and Mechanical Properties of Different Textile Fabrics
}

\author{
Zakary Ahmed, Khaled Charradi, Sherif MAS Keshk* and Radhouane Chtourou \\ Research and Technology Center of Energy, Nanomaterials and Systems for Renewable Energy Laboratory, Tunisia
}

Submission: July 20, 2020; Published: July 27, 2020

*Corresponding author: Sherif MAS Keshk, Nanomaterials and Systems for Renewable Energy Laboratory, Research and Technology Center of Energy, Technoparc Borje Cedria, BP 095 Hammam Lif, Tunisia

\begin{abstract}
The increase in awareness of the destruction caused by synthetic fibers on the environment has led to the development of eco-friendly fibers. The researchers have shown a lot of interest in developing such fiber composite which can replace the synthetic fibers. As a result, there is an increase in demand for commercial use of the natural fiber-based composites in recent years for various industrial sectors. In this review, the different sources of natural fibers, their properties, modification of natural fibers and the effect of treatments on natural fibers were summarized.

Keywords: Fiber; Physical properties; Thermal properties; Mechanical properties
\end{abstract}

\section{Introduction \& Discussion}

Raw material is one of the most important factors affecting the physicochemical properties of textile materials. Thus, fiber type, fiber property, fiber mixing condition and fiber handling are essential to meet the expected features according to the usage area of the clothing. There were just characteristic fiber types, for example, cotton, fleece, silk, hemp, ramie, jute and kenaf that could be utilized as material items in textile industry. Since the creation of rayon strands called artificial silk, the production and use of artificial fibers have quickly developed [1]. Within this time, the fiber assorted variety of the makers has expanded and the chance of utilizing numerous fiber types with various properties has been made. All fibers have various points of interest and weaknesses, and their needs shift as per their use territory and proposed purposes. To provide better attributes in clothing techniques it is attempted to consolidate the worthwhile properties of the fibers and to forestall disadvantageous sides of the fibers by blending [2]. This is the purpose why some researchers focus on the analyzing the effect of the fibers and their blends on physicochemical properties of the fabrics and textile. In the case of kenaf fiber, loss of viscosity has been found to be highly sensitive to the conditions under which the textile process occurs [3]. Using a sequence of acidified sodium chlorite, ammonium oxalate and $1 \%$ sodium hydroxide treatment generated good quality kenaf fiber [4]. Cotton fabrics coated with chitosan film containing titanium oxide and/or zirconium oxide (composite) showed a positive impact on both the UV-protection and the Gram-positive bacteria (S. aureus) and Gram-negative bacteria (E. coli) (Figure 1) [5].
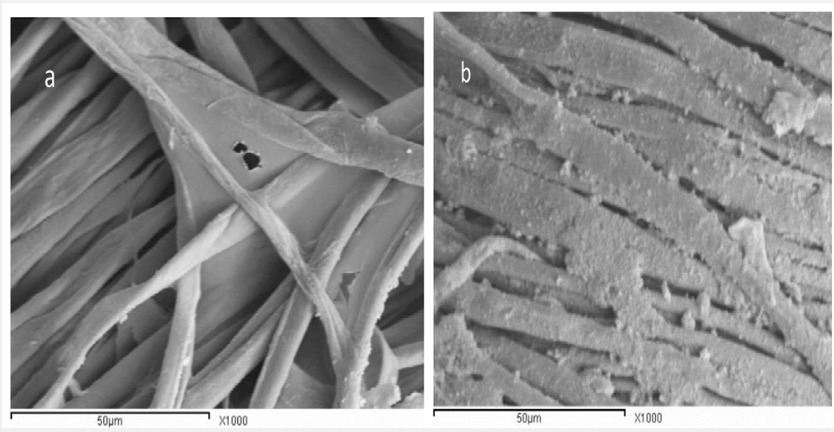

Figure 1: Scanning electron microscope for

a. cotton fabric and

b. cotton blend. 
Furthermore, the presence of magnetic nanoparticles (MNPs) in cellulosic fiber showed an expected flame-retardant effect because of a higher charge yield observed of the blend (Figure 2) $[6,7]$. The presence of natural hydroxy appetite (HAp) in cellulosic fibers showed a good porous structure and a high compressive strength (Table 1). Furthermore, the blend shows mass losses at higher temperatures, confirming higher thermal stability as compared to cellulosic fiber, conforming with the obtained thermodynamic results [8]. On the other hand, heat flow through the textile assembly mostly depends on the thermal conductivity of the fibrous material, fiber volume, construction of the fabric, and orientation of fiber with respect to the heat flow direction $[9,10]$. Significant research works determine the effective thermal conductivity $(\mathrm{Km})$ and thermal resistance of fabric using mathematical modelling and numerical analysis [11].
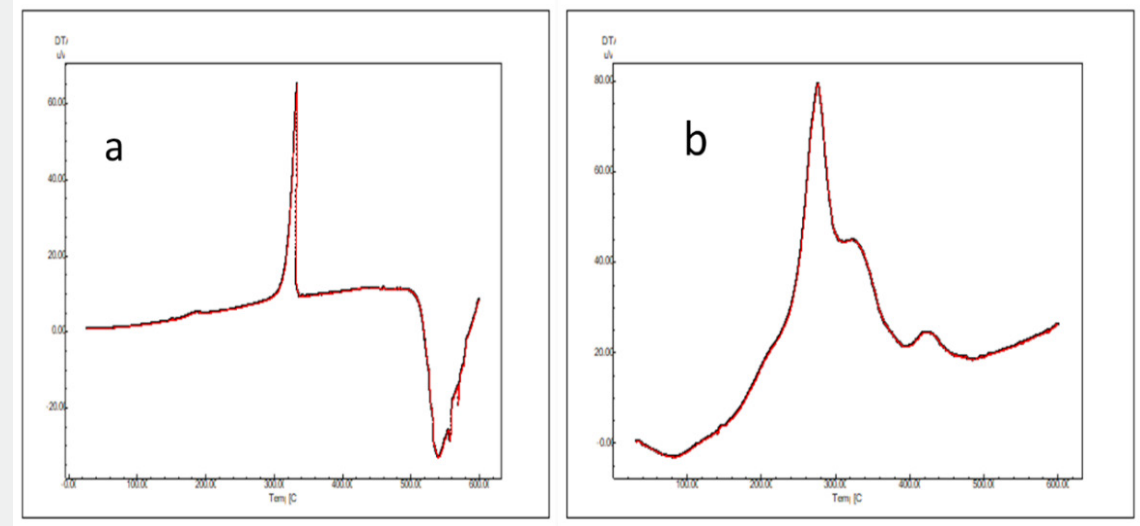

Figure 2: DTA for

a. cotton fabric and

b. cotton/MNPs blend.

Table 1: Thermodynamics Activation Parameters for Cellulose and HAp/Cellulose Blend using Coats-Redfern (CR) and Horowitz-Metzger (HM) Methods.

\begin{tabular}{|c|c|c|c|c|c|c|c|c|c|c|c|c|}
\hline & \multicolumn{2}{|c|}{$\mathrm{E}, \mathrm{kJ} \mathrm{\textrm {mol } ^ { - 1 }}$} & \multicolumn{2}{|c|}{$A, s^{-1}$} & \multicolumn{2}{|c|}{$\underset{\mathbf{K}^{-1}}{\Delta S^{*}, \mathrm{~J} \mathrm{~mol}^{-1}}$} & \multicolumn{2}{|c|}{$\Delta \mathrm{H}^{*}, \mathbf{k J ~ m o l} \mathbf{~}^{-1}$} & \multicolumn{2}{|c|}{$\Delta G^{*}, \mathbf{k J ~ m o l}^{-1}$} & \multirow{2}{*}{ DTG $_{\text {max }}{ }^{\circ} \mathrm{C}$} & \multirow{2}{*}{ Step } \\
\hline & CR & HM & CR & HM & CR & HM & CR & HM & CR & HM & & \\
\hline Cellulose & $295(r=0.99993)$ & $284(\mathrm{r}=0.99991)$ & $1.50 \mathrm{E}+18$ & $9.86 \mathrm{E}+20$ & 96.5 & 150 & 254 & 278 & 191 & 180 & 320 & $2^{\text {nd }}$ \\
\hline $\begin{array}{c}\text { HAp }_{\mathrm{a}} / \\
\text { cellulose }\end{array}$ & $103(\mathrm{r}=0.99993)$ & $120(\mathrm{r}=0.99991)$ & $3.26 \mathrm{E}+05$ & $1.66 \mathrm{E}+07$ & 146 & 113 & 97.2 & 114 & 196 & 191 & 401 & $2^{\text {nd }}$ \\
\hline
\end{tabular}

The mechanical properties of natural or composite fibers such as fiber strength, elongation, elasticity, and modulus of elasticity are very important in textile fabrics. Mechanicals properties are dependent to several parameters, such as, Fiber type and morphology, filler, fabric structure, methodology and machine conditions. Many diverse mechanical stresses applied to cotton fibers in all the process level $[12,13]$. Fibers with superior tensile properties are seeked because these can:

- $\quad$ Resist failure and quality degradation during the processing and

- $\quad$ Higher quality of yarn and final product are reached.

Many factors such as genetics, environmental conditions, and agronomic practices may contribute to within-plant variability in fiber length $[14,15]$. The quality of the Natural fiber also affect mechanical properties, Cotton and lint with excessive trash may excessively cleaning sequences at the gin [16]. The cleaning process (at the gin) is aggressive and tends to decrease mechanical properties of the fibers [17]. Trash and contaminant removal at the gin optimized to preserve fiber quality and so the final textile product [17]. The stress-strain curve behavior of a textile fiber also depends on some other factors. One of the important factors is the earlier mechanical history of the fiber. Another important factor is temperature. In addition, the mechanical characteristics of the fiber depend on the aging time with temperature. The mechanical history along with aging time and temperature affects this viscoelastic behavior [18]. Also, Exceeding the temperature and pressure of hot compaction (over certain values), the mechanical properties of ramie fiber-based composite were found to be deteriorated [19]. The fiber processing in itself, can cause critical change in mechanical behavior of the fiber, For 
Natural fiber, As shown by Neagu (2006) [20], fiber wall material is damaged, and walls have collapsed resulting in fibers with lower stiffness and strength. However, fillers addition can affect the energy absorption of the fibers via changing the length and thickness of the composite tubes on the absorbed energy of natural silk/epoxy composite [21]. Whereas mechanical and fracture properties of cellulose-fiber-reinforce epoxy laminates determined the influence of the fiber loading on the mechanical behavior of the cellulose fiber/epoxy composites. They observed that raising the content of cellulose fiber in the polymer matrix enhances mechanical properties [22].

Benjamin et al. [23] examined the influence of lignin on the mechanical properties of the hemp/epoxy composites. They observed that composite showed 145\% improvement in impact strength on the addition of $5 \% \mathrm{w} / \mathrm{w}$ lignin. Thermal properties are mostly affected by porosity, moisture regain and density. Fabric weight, thickness, air permeability and density influence hydric properties of textile. Besides, the water vapor permeability index depends on fabric weight, porosity, moisture regain, air permeability and density.

\section{Conclusion}

Increased environmental consciousness has resulted in the consumption of natural fiber as an effective reinforcement fiber in polymer matrix composites. The fibers are usually extracted from plants and animals often offer poor resistance to moisture and incompatible nature of fibers become the main disadvantage. Therefore, modification of fibers properties has done through chemical treatments of fibers that improve the adhesion between the fibers and matrix and enhance the physicochemical and mechanical properties of the composites.

\section{References}

1. Song G (2011) Improving Comfort in Clothing. In: $1^{\text {st }}$ (edn.), Woodhead Publishing Limited, UK, pp. 1-496.

2. Morton WE, Hearle JWS (2008) Physical Properties of Textile Fibers In: $4^{\text {th }}$ (edn.), Woodhead Publishing Limited, Uk, pp. 1-746.

3. Nezamoleslami A, Suzuki T, Nishida, Ueno T (1998) Biobleaching of kenaf bast fiber, soda-AQ pulp using white-rot fungus. Tappi Journal 81: 179-183.

4. Keshk SMAS, Suwinarti W, Sameshima K (2006) Physicochemical characterization of different treatment sequences on kenaf bast fiber. Carbohydrate Polymers 65(2): 202-206.

5. Gouda M, Keshk SMAS (2010) Evaluation of multifunctional properties of cotton fabric based on metal/chitosan film. Carbohydrate Polymers 80(2): 504-512.
6. Keshk SMAS, Zahar AA, Al-Sehemi AG, Irfan A, Bondock S (2019) Synthesis and physicochemical characterization of a magnetic nanoparticles/dialdehyde cellulose composite as a flame retardant. Mater Res Express 6(2): 025312.

7. Keshk Sherif MAS, Bondock S, Youssef Ayman MS, El-Zahhar Adel A (2019) Novel synthesis of flame-retardant magnetic nanoparticles/ hydroxyl acid cellulose-6-phosphate composite. Mater Res Express 6(8): 085310.

8. Alghamdi MM, Awad NS, Al-Karim AA, Al-Sharaey, Keshk Sherif MAS (2019) Physicochemical Characterization of the Natural Hydroxyapatite/ Cellulose Composite. Indian J fiber textile technology 44(1): 45-50.

9. Kawabata S (1986) Measurement of anisotropic thermal conductivity of single fiber. Journal of the Textile Machinery Society of Japan 39(12): T184-T186.

10. Woo SS, Shalev I, Barker RL (1994) Heat and moisture transfer through nonwoven fabrics: Part I: Heat transfer. Textile Res J 64(3): 149-162.

11. Schuhmeister J, Akad Wien Ber K, (1987) Math. Nature Klasse 76: 283.

12. Faulkner WB, Hequet John EF, Wanjura D, Boman R (2012) Relationships of cotton fiber properties to ring-spun yarn quality on selected High Plains cottons. Textile Res J 82(4): 400-414.

13. El Moghazi YE, Broughton R, Lynch WK (1990) A Statistical Approach for Determining the Technological Value of Cotton Using HVI Fiber Properties. Textile Res J 60: 495-500.

14. Meredith WR Jr, Ranney CD, Laster ML, Bridge RR (1973) Agronomic Potential of Nectariless Cotton. J Environmental quality 2(1): 141-144.

15. Bednarz CW, Nichols RL, Brown SM (2006) Plant density modifies within-canopy cotton fiber quality. Crop Science 46(2): 950-956.

16. Anthony WS, William D Mayfield (1994) Cotton Ginners Handbook. Agricultural Handbook 503 section. pp. 1-346.

17. Foulk J, Hughs SE, Armijo C (2013) Upland Fiber Changes Due to Ginning and Lint Cleaning. J Cotton Sci 17(2): 115-124.

18. Kumar S, Gupta VB (1978) Nonlinear viscoelastic model for textile fibers. Textile Res J 48(7): 429-431.

19. Mahjoub R, Yatim JM, Sam ARM, Raftari M (2014) Characteristics of continuous unidirectional kenaf fiber reinforced epoxy composites. Mater Design 64: 640-649.

20. Cristian Neagu R, Kristofer Gamstedt E, Berthold F (2006) Stiffness contribution of various wood fibers to composite materials. J Compos Mater 40(8): 663-699.

21. Oshkovr S, Eshkoor R, Taher S, Ariffin AK, Azhari CH (2012) Crashworthiness characteristics investigation of silk/epoxy composite square tubes. Compos Struct 94(8): 2337-2342.

22. Low IM, McGrath M, Lawrence D, Schmidt P, Lane J, et al. (2007) Mechanical and fracture properties of cellulose-fibre-reinforced epoxy laminates. composites part A: Appl. Sci Manufacturing 38(3): 963-974.

23. Wood MB, Coles SR, Maggs S, Meredith J, Kirwan K (2011) Use of lignin as a compatibilizer in hemp/epoxy composites. Compos Sci Technol 71: 1804-1810. 


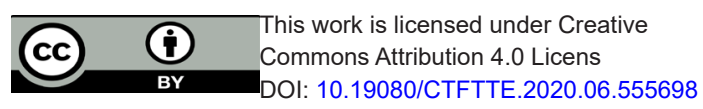

- Quality Editorial service

- Swift Peer Review

- Reprints availability

- E-prints Service

- Manuscript Podcast for convenient understanding

- Global attainment for your research

- Manuscript accessibility in different formats

( Pdf, E-pub, Full Text, Audio)

- Unceasing customer service

Track the below URL for one-step submission https://juniperpublishers.com/online-submission.php 